\title{
Isodeoxyelephantopin from Elephantopus scaber (Didancao) induces cell cycle arrest and caspase-3-mediated apoptosis in breast carcinoma T47D cells and lung carcinoma A549 cells
}

\author{
Farha Arakkaveettil Kabeer ${ }^{1}$, Geetha Balakrishnan Sreedevi², Mangalam Sivasankaran Nair ${ }^{3}$, \\ Dhanya Sethumadhavannair Rajalekshmi ${ }^{3}$, Latha Panickaparambil Gopalakrishnan ${ }^{2}$ and Remani Prathapan ${ }^{1 *}$
}

\begin{abstract}
Background: Isodeoxyelephantopin (IDOE) isolated from Elephantopus scaber L. (Didancao) is used in Chinese medicine for the treatment of some types of cancer. The anti-cancer mechanism of IDOE remains unclear. This study aims to investigate the antiproliferative activity of IDOE on breast carcinoma T47D cells and lung carcinoma A549 cells.

Methods: The growth inhibitory effects of IDOE on breast carcinoma T47D cells, lung carcinoma A549 cells, and normal lymphocytes were evaluated by the MTT assay. Morphological analysis of apoptosis induction was performed by acridine orange/ethidium bromide dual-staining and Hoechst 33342 nuclear staining. The cell cycle profile, caspase-3 expression, and annexin $\vee$ staining were evaluated by flow cytometry.
\end{abstract}

Results: IDOE inhibited the growth of A549 and T47D cells in a dose- and time-dependent manner with IC 50 values of 10.46 and $1.3 \mu \mathrm{g} / \mathrm{mL}$, respectively. IDOE was not significantly toxic to normal lymphocytes. The cells became detached from the monolayer and rounded up, had fragmented nuclei and condensed chromatin, and the numbers of apoptotic cells increased $(P=0.0003)$. IDOE-induced cell death was associated with activated caspase-3 expression followed by cell cycle arrest at G2/M phase.

Conclusions: IDOE inhibited the proliferation of breast cancer cells and lung carcinoma cells and induced caspase-3-mediated apoptosis and cell cycle arrest in the treated cells.

\section{Background}

Elephantopus scaber L. (Asteraceae) is a well-known Chinese medicine that is widely used in the treatment of nephritis, edema, dampness, chest pain, fever and cough of pneumonia, and scabies in Tropical Africa, Eastern Asia, Indian Subcontinent, Southeast Asia, and Australia [1]. Infusion and decoctions of the whole plant are used to stimulate diuresis, reduce fever, and eliminate bladder stones [2]. Extensive phytochemical investigations of the plant isolated different secondary metabolites such as

\footnotetext{
*Correspondence: remanipr@gmail.com or remanip@rcctvm.gov.in 'Division of Cancer Research, Regional Cancer Centre, Thiruvananthapuram, Kerala, India

Full list of author information is available at the end of the article
}

flavonoids, lignans, terpenoids, elephantopin, triterpenes, stigmasterol, epifriedelinol, lupeol, and sterols [3]. Recently, anticancer activity of $E$. scaber has been reported for different types of human tumor cell lines [4].

E. scaber has been used in Chinese medicinal with hepatoprotective, anticancer, and antibacterial activities [5-7]. The plant has been reported to contain sesquiterpene lactones, deoxyelephantopin, Isodeoxyelephantopin (IDOE), and scabertopin [8], and the IDOE isolated from the plant exhibited cytotoxicity toward SMMC7721, HeLa, and Caco2 cells with $\mathrm{IC}_{50}$ values of $18.28,14.59$, and $18.28 \mu \mathrm{M}$, respectively, after $48 \mathrm{~h}$ of treatment [9]. IDOE was also found to inhibit the growth of KBM-5 human chronic 
myeloid leukemia cells by altering transcription factor NF-kB expression [10].

However, its modes of actions on lung adenocarcinoma and breast carcinoma cell lines have not yet been elucidated. This study aims to investigate the antiproliferative activity of IDOE on breast carcinoma T47D cells and lung carcinoma A549 cells.

\section{Methods}

\section{Materials and reagents}

DMEM, RPMI 1640 medium, PI, ribonuclease-A, Triton X-100, 3-(4,5-dimethylthiazol-2-yl)-2,5-diphenyltetrazolium bromide (MTT), and Hoechst 33342 were obtained from Sigma Chemical Co. (St. Louis, MO, USA). Dimethyl sulfoxide (DMSO) was purchased from Merck Co. (Darmstadt, Germany). Fetal bovine serum (FBS) was obtained from Gibco BRL (Grand Island, NY, USA). The solvents used for purification and spectroscopic studies (AR grade) and Silica gel were obtained from Merck, Germany. Experimentation procedures described including maintenance of cell lines were reviewed and approved by institutional Ethics Committee (Regional Cancer Centre, Trivandrum, Kerala).

\section{Drugs}

IDOE (Figure 1) with a purity of $99 \%$ was isolated, purified, and identified from E. scaber as previously described [11]. Briefly, fresh E. scaber whole plants were dried, powdered, and extracted with chloroform for $12 \mathrm{~h}$. The chloroform extract was concentrated, subjected to silica gel column chromatography, and eluted with hexane and a gradient of hexane-ethyl acetate. The fractions eluted with $15 \%$ ethyl acetate in hexane were purified by column chromatography and eluted with hexane and a gradient of hexane-ethyl acetate. IDOE was crystallized from the fractions eluted with $10 \%$ ethyl acetate in hexane. The structure of IDOE was

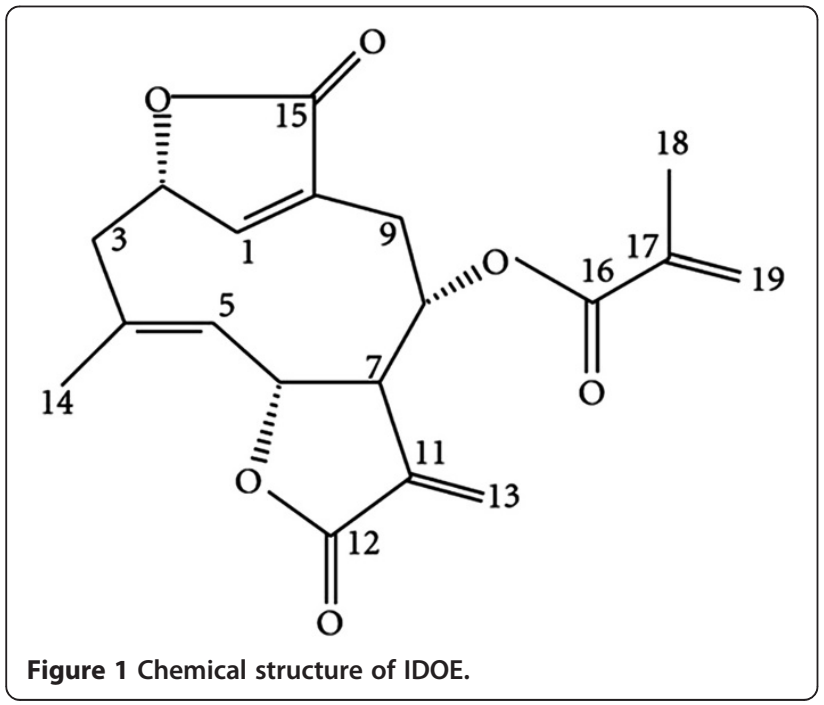

elucidated by infrared spectrometer (Bruker FT IR, Bruker Optik GMBH, Germany), ${ }^{1} \mathrm{H}$, and ${ }^{13} \mathrm{C}$ NMR spectrometry (Bruker AMX $500 \mathrm{MHz}$ NMR, Bruker, Switzerland) and confirmed by the spectral data and melting point of the compound reported in the literature [8]. IDOE was dissolved in DMSO at a concentration of $10 \mathrm{mM}$ and stored at $-20^{\circ} \mathrm{C}$. Dilutions of IDOE were made in culture medium immediatedly before the experiments. Paclitaxel (Sigma, St. Louis, MO, USA) was used as a positive control.

\section{Cell culture}

Lung adenocarcinoma A549 and breast carcinoma T47D cell lines were obtained from the National Centre for Cell Sciences (India). The cells were cultured in DMEM containing $10 \% \mathrm{FBS}$ and maintained at $37^{\circ} \mathrm{C}$ in a $5 \% \mathrm{CO}_{2}$ environment.

Adult human peripheral blood samples were drawn for isolation of normal human lymphocytes. The blood specimens were diluted 1:1 with phosphate-buffered saline (PBS) (Merck, Germany) and normal lymphocytes were separated by a standard Ficoll-Paque Plus gradient method (GE Healthcare, Pittsburgh, USA). Normal lymphocytes were resuspended in RPMI- 1640 medium with $10 \%$ FBS for cytotoxicity assay.

\section{Cytotoxicity assay}

Cell viability was assessed by the MTT assay. The cells were seeded in 96-well plates at $5 \times 10^{3}$ cells/100 $\mu \mathrm{L} /$ well. IDOE concentrations ranging from $0-25 \mu \mathrm{g} / \mathrm{mL}$ for A549 cells and $0-5 \mu \mathrm{g} / \mathrm{mL}$ for T47D cells were added. The plates were incubated at $37^{\circ} \mathrm{C}$ for 24,48 , and $72 \mathrm{~h}$. MTT $(5 \mathrm{mg} / \mathrm{mL})$ was then added to each well and incubated in the dark for $2 \mathrm{~h}$ at $37^{\circ} \mathrm{C}$. Lysis buffer $(100 \mu \mathrm{L})$ was added to each well and incubated for $4 \mathrm{~h}$ to dissolve the formazan crystals produced. The absorbances of the wells were measured using a microplate reader (Biotek, USA) at a wavelength of $570 \mathrm{~nm}$. The growth inhibition was assessed using the following equation:

$$
\begin{aligned}
\% \text { of growth inhibition }= & {[100-(\text { absorbance of treated cells }} \\
& / \text { absorbance of control cells }) \\
& \times 100]
\end{aligned}
$$

The respective half-maximal inhibitory concentration $\left(\mathrm{IC}_{50}\right)$ values after $48 \mathrm{~h}$ of incubation were determined for each cell line. Normal lymphocytes $\left(2 \times 10^{4}\right.$ cells $\left./ 100 \mu \mathrm{L}\right)$ were seeded in 96-well plates. IDOE was added at concentrations ranging from $0-35 \mu \mathrm{g} / \mathrm{mL}$ and incubated for $72 \mathrm{~h}$. The viability of lymphocytes was measured by the same procedure described above. 


\section{Morphological changes of tumor cells observed by light microscopy}

A549 and T47D cells were seeded in 96-well plates $\left(2 \times 10^{4}\right.$ cells/well $)$ and incubated overnight to allow adhesion. The cells were treated with IDOE at concentrations of 10.46 and $1.3 \mu \mathrm{g} / \mathrm{mL}$ for $48 \mathrm{~h}$. Morphological changes were observed by phase-contrast microscopy (Model IX51; Olympus, Japan).

\section{Acridine orange/ethidium bromide staining}

The morphology of apoptotic cells was analyzed under a fluorescence microscope (Model IX51; Olympus, Japan) by staining IDOE-treated cells with acridine orange and ethidium bromide.

\section{Hoechst 33342 staining}

Morphological analyses of apoptosis were performed by staining the cells with Hoechst 33342. The treated A549 and T47D cells were washed twice with PBS and stained with Hoechst 33342 for $1 \mathrm{~h}$ at room temperature. The Hoechst-stained nuclei were visualized by a fluorescence microscope (Model IX51; Olympus, Japan).

Annexin V-FITC/propidium iodide (PI) double-staining assay Annexin V-FITC/propidium iodide (PI) double-staining was performed with an Annexin V-FITC Kit (BD
Bioscience, USA). A549 and T47D cells were treated with IDOE at concentrations of 10.46 and $1.3 \mu \mathrm{g} / \mathrm{mL}$ for $48 \mathrm{~h}$. The cells were trypsinized, rinsed twice with PBS, and resuspended in $1 \times$ binding buffer. The cells were labeled with $5 \mu \mathrm{L}$ of FITC-conjugated annexin $\mathrm{V}$ and $5 \mu \mathrm{L}$ of PI according to the manufacturer's instructions. After incubation in the dark for $15 \mathrm{~min}$ at room temperature, $400 \mu \mathrm{L}$ of binding buffer was added and the samples were immediately analyzed with a flow cytometer (Becton Dickinson, San Jose, CA). The annexin $\mathrm{V}$-FITC ${ }^{-} / \mathrm{PI}^{-}$population was regarded as normal, while the annexin V-FITC ${ }^{+} / \mathrm{PI}^{-}$and Annexin V-FITC ${ }^{+} / \mathrm{PI}^{+}$ populations were taken as measurements of early and late apoptotic cells, respectively.

\section{Detection of caspase 3 expression}

Caspase-3 expression was evaluated with a FITC-conjugated Anti-caspase-3 Antibody Detection Kit (BD Bioscience, USA) in accordance with the manufacturer's instructions. IDOE-treated tumor cells $\left(1 \times 10^{6}\right.$ cells $)$ were collected, washed in PBS, resuspended in $500 \mu \mathrm{L}$ of BD cytofix solution, and incubated for $20 \mathrm{~min}$ on ice. The cells were stained with antibody solution $(20 \mu \mathrm{L}$ of antibody in $100 \mu \mathrm{L}$ of wash buffer) and incubated for a further $30 \mathrm{~min}$ at room temperature. The samples were analyzed by flow cytometry.
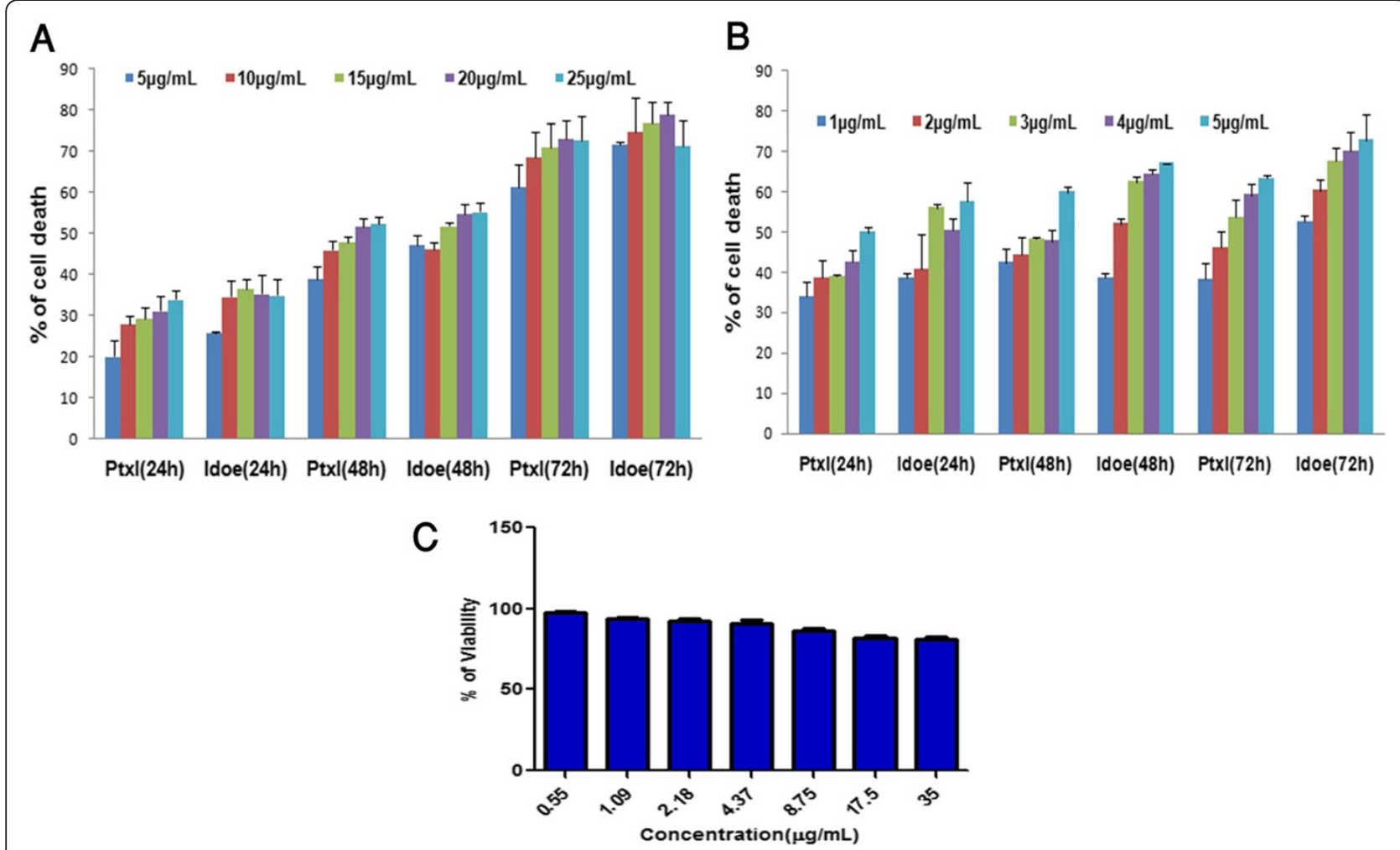

Figure 2 Effect of IDOE on the cell viability of (A) A549 (B) T47D and (C) Normal Lymphocytes. Cells were treated with IDOE at various concentrations for 24, 48 and $72 \mathrm{~h}$ and cell viability was determined by MTT assay. Paclitaxel (Ptxl) was used as positive control. *** $P<0.001$ compared to the control. 


\section{Cell cycle analysis}

Following IDOE exposure for $48 \mathrm{~h}, 1 \times 10^{6}$ cells were collected, washed in PBS, fixed in 70\% ethanol, and kept at $4^{\circ} \mathrm{C}$ overnight. The cell pellet was then washed again with PBS, resuspended in $200 \mu \mathrm{L}$ of cold PBS, and stained with PI solution [0.01\% Triton X-100, $10 \mu \mathrm{L}$ RNase A (10 mg/mL) and $20 \mu \mathrm{L}$ PI $(1 \mathrm{mg} / \mathrm{mL})]$ for 30 min in ice. The total cellular DNA content was analyzed by flow cytometry (Becton Dickinson, San Jose, CA).

\section{Statistical analysis}

Data were presented as the mean \pm standard deviation. The $\mathrm{IC}_{50}$ values were determined by the EasyPlot program. Statistical analysis was performed using Graph Pad Prism 5 (GraphPad Prism software Inc., San Diego, USA). Difference between two groups was analyzed by two-tailed Student's $t$ test, and that between three groups was analyzed by one-way ANOVA followed by Tukey's multiple comparison test. A $P$ value of $<0.05$ was considered statistically significant.

\section{Results}

IDOE suppresses the growth of tumor cells without affecting lymphocytes

In comparisons, the cell growth inhibition effect of IDOE was more effective on T47D cells than on A549 cells (Figure $2 \mathrm{~A}$ and $\mathrm{B}$ ). The $\mathrm{IC}_{50}$ values were $10.46 \mu \mathrm{g} / \mathrm{mL}$ for A549 cells and $1.3 \mu \mathrm{g} / \mathrm{mL}$ for T47D cells. Longer exposure of the cells to IDOE resulted in lower concentrations required to achieve the $\mathrm{IC}_{50}$ in both A549 and T47D cells $(P<0.001)$. The determined $\mathrm{IC}_{50}$ values were used for the subsequent experiments. IDOE

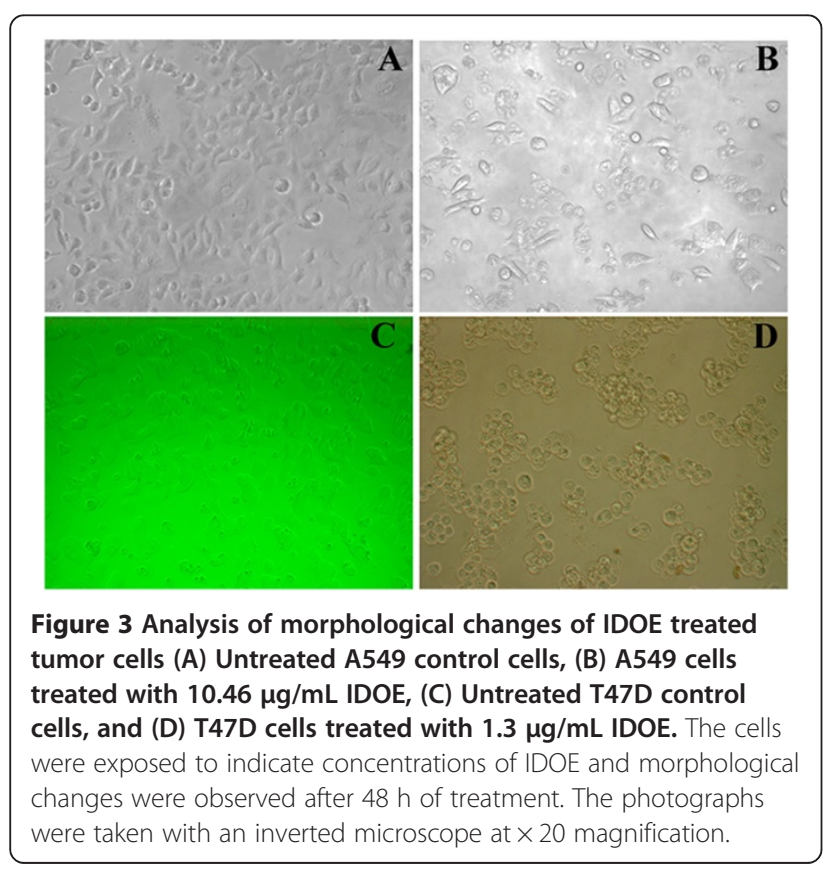

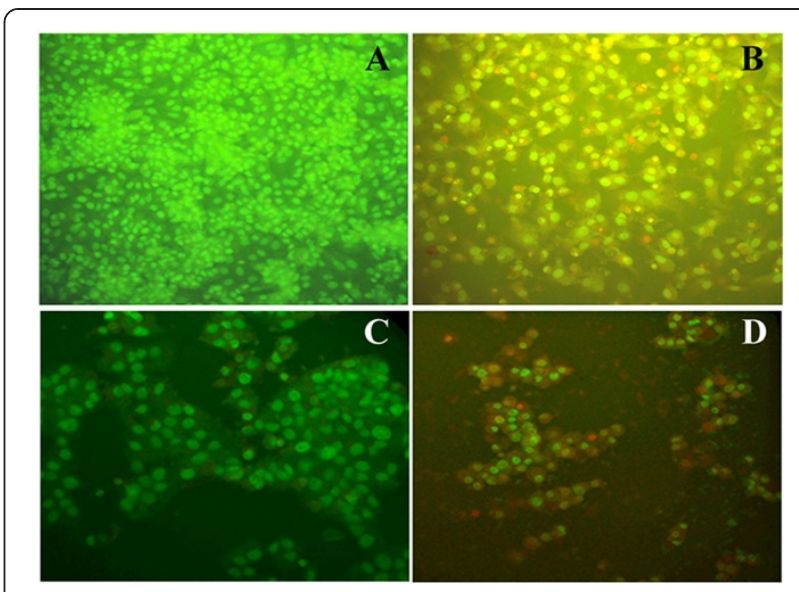

Figure 4 Acridine orange/ethidium bromide double staining to analyze the apoptotic morphology of IDOE treated tumor cells. (A) Untreated A549 control cells, (B) A549 cells treated with $10.46 \mathrm{\mu g} / \mathrm{mL}$ IDOE, (C) Untreated T47D control cells, and (D) T47D cells treated with $1.3 \mu \mathrm{g} / \mathrm{mL}$ IDOE. Viable cells (bright green nuclei); early apoptotic cells (bright green condensed nuclei); late apoptotic cells (red nuclei with condensed or fragmented chromatin) under fluorescent microscopy.

was less toxic toward peripheral blood lymphocytes (Figure 2C).

Morphological analysis of tumor cells by light microscopy After $48 \mathrm{~h}$ of incubation with IDOE, many of the cells showed cytoplasmic shrinkage and loss of normal nuclear architecture, became detached from the flask, and were floating in the medium (Figure 3).

\section{Fluorescence microscopic analysis of apoptotic cells}

As shown in Figure 4, acridine orange/ethidium bromide staining revealed the characteristic features of apoptosis.

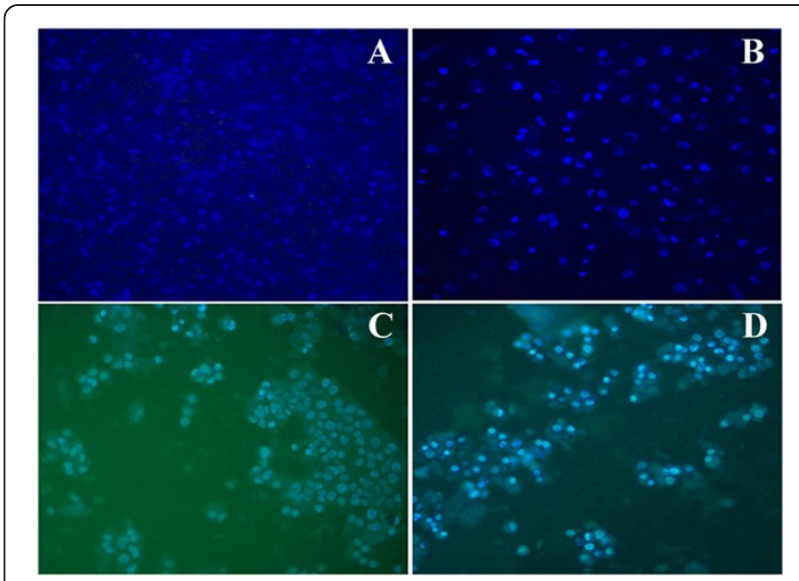

Figure 5 IDOE-induced apoptosis in tumor cells. (A) Untreated A549 control cells, (B) A549 cells treated with $10.46 \mu \mathrm{g} / \mathrm{mL}$ IDOE, (C) Untreated T47D control cells, and (D) T47D cells treated with $1.3 \mathrm{\mu g} / \mathrm{mL}$ IDOE. The cells were treated with IDOE for $48 \mathrm{~h}$, stained with Hoechst $33342(10 \mu \mathrm{M})$ and examined by fluorescence microcopy at a magnification of $\times 20$. 
The cytoplasm and nucleus of normal cells appeared green under fluorescence microscopy, suggesting that IDOE was able to trigger cell death through apoptosis.

The IDOE-treated cells stained with Hoechst 33342 $(10 \mu \mathrm{M})$ revealed condensed chromatin, fragmented nuclei, and nuclear shrinkage (Figure 5). The number of apoptotic cells increased after treatment with IDOE for $48 \mathrm{~h}(P=0.0003)$.

\section{Annexin V staining of IDOE-treated cells}

In annexin V staining, control A549 cells showed 1\% early apoptotic cells and $6.2 \%$ late apoptotic cells, whereas
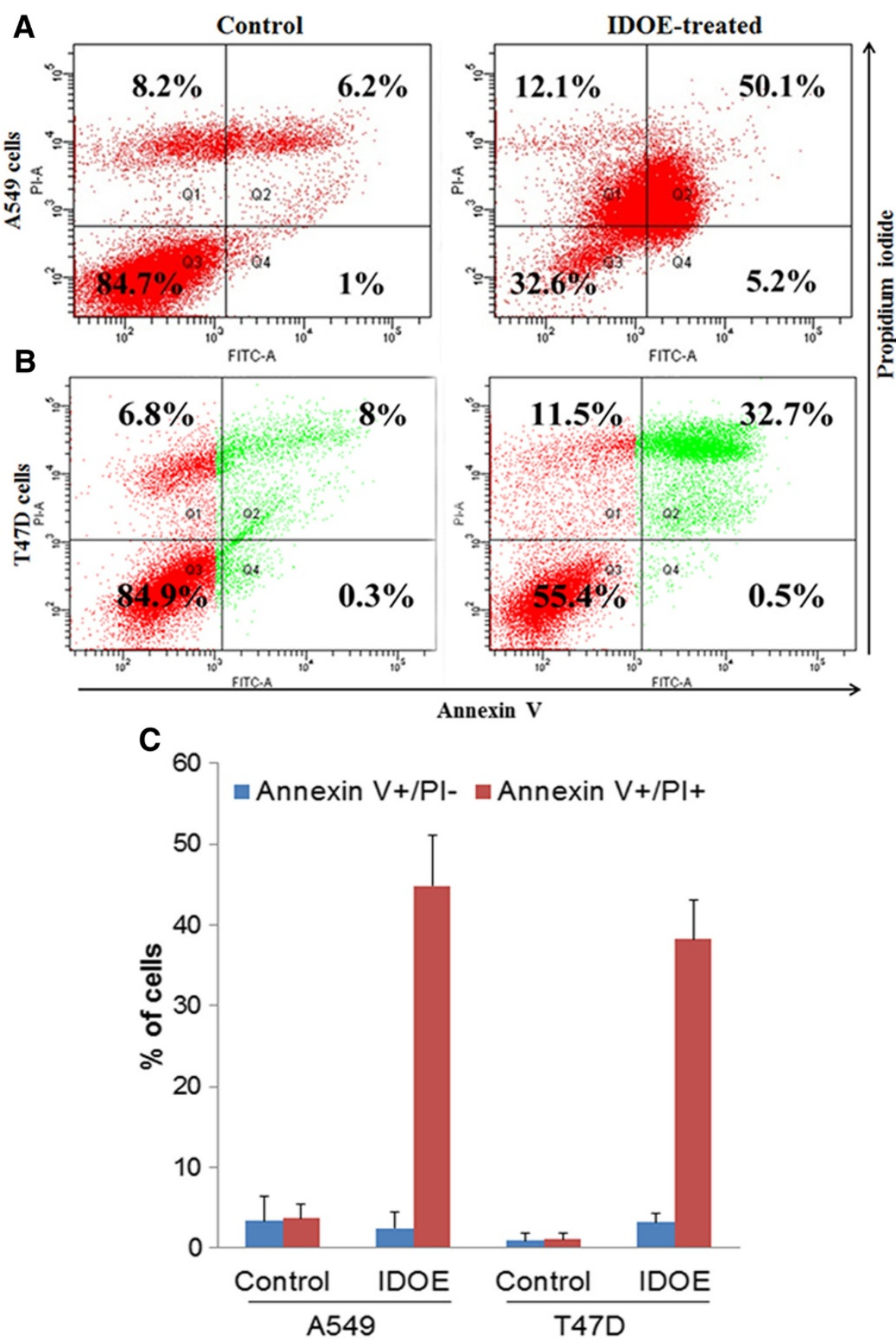

Figure 6 Flow cytometric analysis of Annexin V and propidium iodide staining in cells treated by IDOE (A) A549 cells (B) T47D cells. The viable cell populations are in the lower left quadrant (Annexin V-/PI-), the cells at the early apoptosis are in the lower right quadrant (Annexin $\mathrm{V}+/ \mathrm{PI}-$ ), and the ones at the late apoptosis are in the upper right quadrant (Annexin $\mathrm{V}+/ \mathrm{PI}+$ ). (C) Data expressed as mean \pm SD from three independent experiments. $P<0.05$ vs control. 
IDOE-treated A549 cells showed 5.2\% early apoptotic cells and $50.1 \%$ late apoptotic cells (Figure 6A).

T47D cells treated with IDOE at $1.3 \mu \mathrm{g} / \mathrm{mL}$ induced apoptosis, with $0.5 \%$ early apoptotic cells and $32.7 \%$ late apoptotic cells, while control T47D cells showed $0.3 \%$ early apoptotic cells and 8\% late apoptotic cells (Figure 6B).

Increased caspase-3 expression levels in IDOE-treated tumor cells

Figure 7 shows the effects of IDOE at the level of caspase-3 induction in tumor cells. There was a significant increase in caspase- 3 activity in the IDOE-treated cells compared with control cells after $48 \mathrm{~h}$ of treatment in both cell lines $(P<0.001)$.

\section{IDOE induces G2/M phase cell cycle arrest}

In A549 cells, the population of cells in G2/M phase increased from $5.3 \%$ to $23.3 \%$ following IDOE treatment for $48 \mathrm{~h}$. Sub-G1 cells comprised $2.9 \%$ of the control cells, whereas treatment with IDOE at $10.46 \mu \mathrm{g} / \mathrm{mL}$ increased the cells in sub-G1 phase to $5.6 \%$ (Figure 8A). At a concentration of $1.3 \mu \mathrm{g} / \mathrm{mL}$,
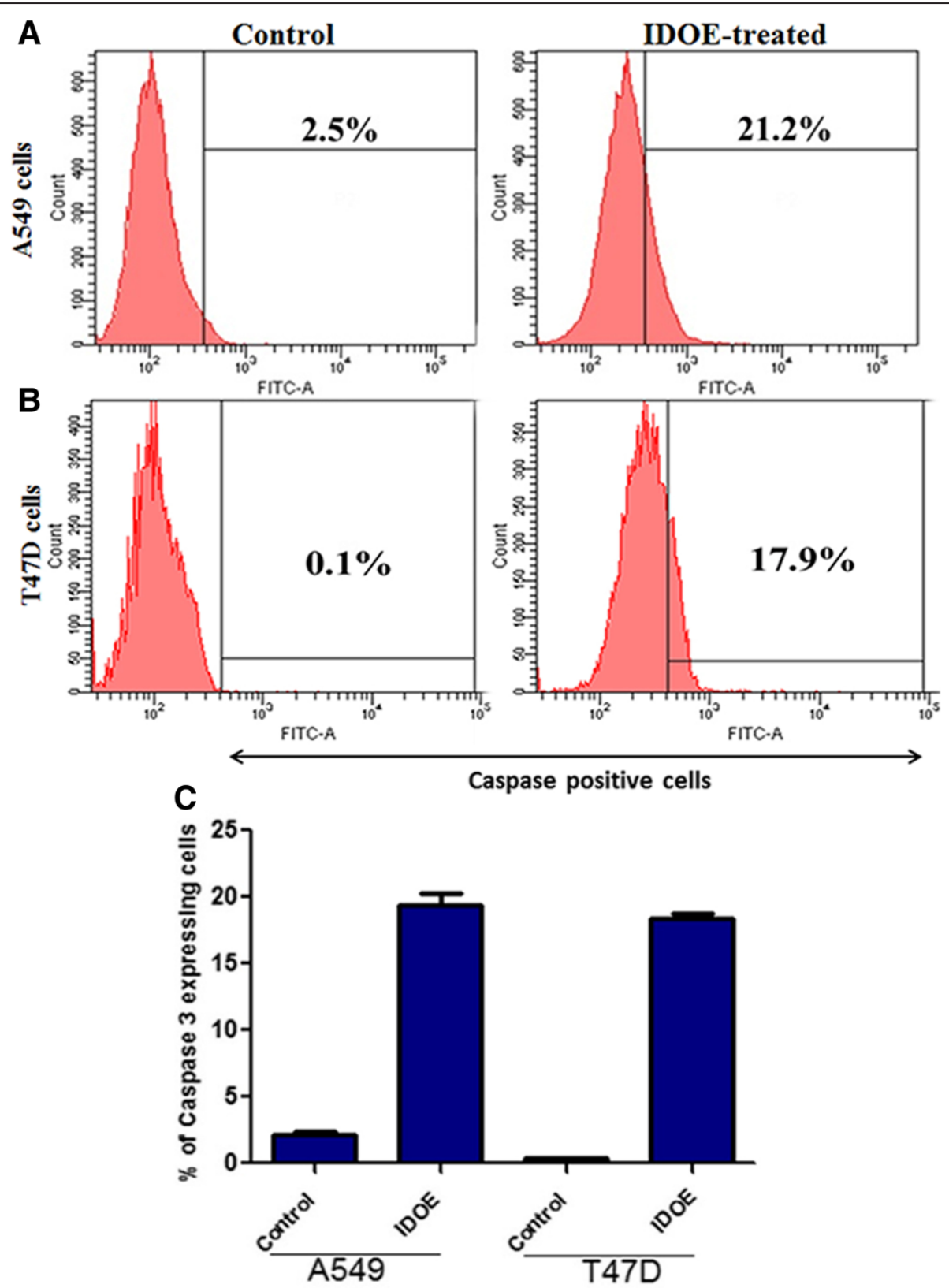

Figure 7 Effect of IDOE on Caspase 3 expression. (A) A549 cells, and (B) T47D cells. The cells were treated with IDOE and Caspase 3 was determined by flow cytometry. (C) Data expressed as mean \pm SD from three independent experiments. $P<0.05$ vs control. 

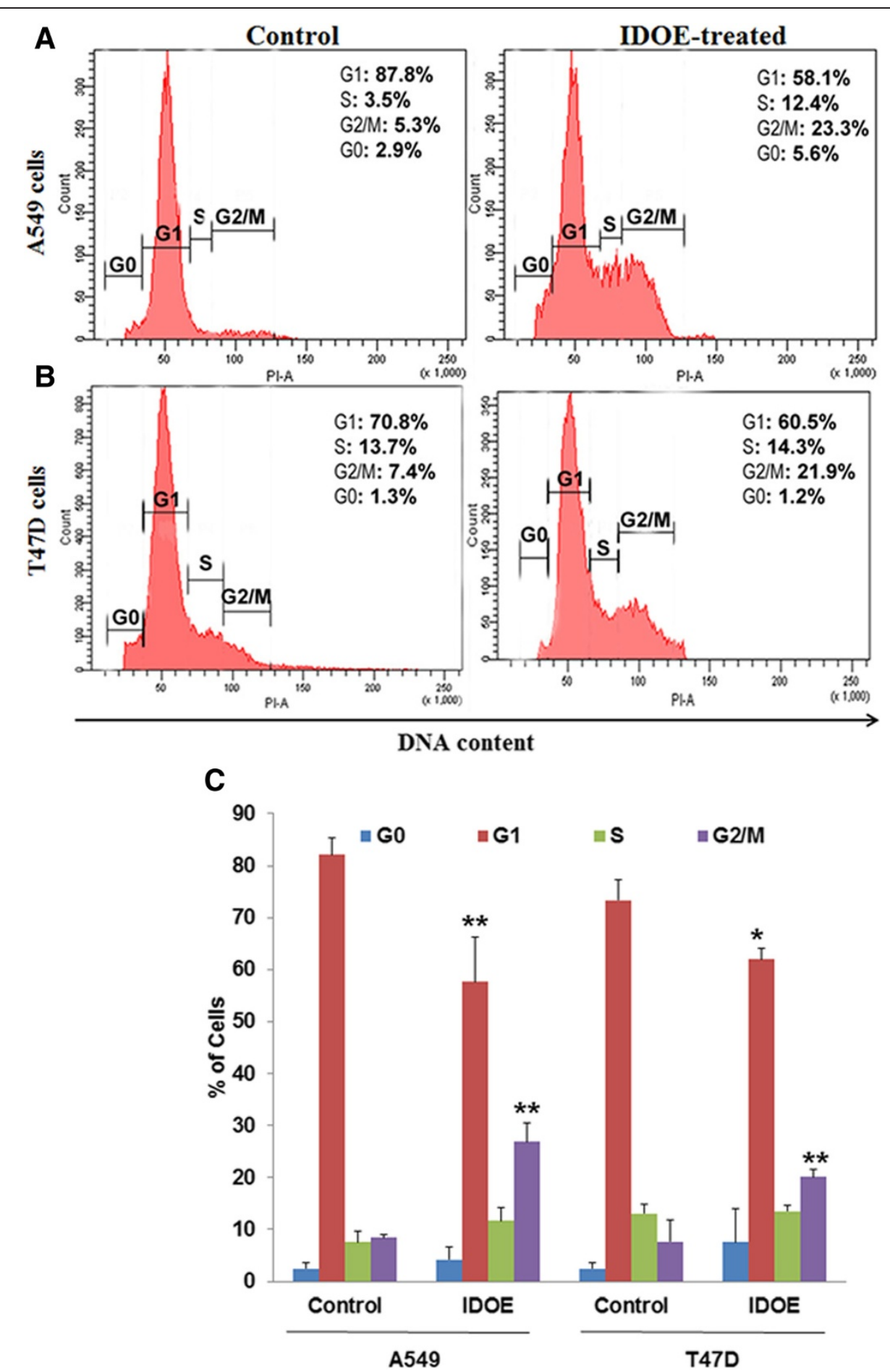

Figure 8 Effect of IDOE on cell cycle progression. (A) A549 cells (B) T47D cells. The cells were treated with IDOE for 48 h. The cell cycle distribution was determined by a flow cytometric analysis of the DNA content after staining with propidium iodide. (C) Data expressed as mean $\pm \mathrm{SD}$ from three independent experiments. $P<0.05$ vs control.

IDOE significantly increased the population of T47D cells in $\mathrm{G} 2 / \mathrm{M}$ phase $(21.9 \%)(P=0.0087)$ (Figure $8 \mathrm{~B})$. IDOE prevented $\mathrm{G} 2 / \mathrm{M}$ transition and consequently induced $\mathrm{G} 2 / \mathrm{M}$ phase arrest.

\section{Discussion}

The basic structural requirement for the cytotoxic activity of a sesquiterpene lactone is the presence of an $\alpha$-methylene- $\gamma$-lactone moiety in the molecule, 
regardless of the differences among structural types [12]. The presence of an $\alpha$-methylene- $\gamma$-lactone moiety in IDOE may play a role in its anticancer effect. The molecular mechanism of IDOE underlying the antitumor activity remains unclear. This study aims to investigate the antiproliferative activity of IDOE toward breast carcinoma T47D cells and lung carcinoma A549 cells and its mechanism of action.

IDOE was non-cytotoxic to peripheral blood lymphocytes. These findings supported the previous report by Geetha et al. [11], indicating that IDOE showed specific cytotoxic activity toward cancer cells and not toward normal lymphocytes.

Many anticancer drugs function primarily to induce apoptosis in cancer cells and prevent tumor development $[13,14]$. The morphological changes of apoptosis observed in most cell types initially start with a reduction in cell volume and condensation of the nucleus [15]. Upon treatment with IDOE for $48 \mathrm{~h}$, both A549 and T47D cells became detached from the monolayer and exhibited by nuclear fragmentation and chromatin condensation. The flow cytometry data obtained with annexin V/PI dual-staining confirmed that IDOE caused apoptosis in these tumor cells. To our knowledge, this is the first report on the apoptosis-inducing activity of IDOE for A549 and T47D tumor cells.

Activated caspases is triggered by signals from either death factors or mitochondrial alterations in the apoptotic process [16]. Activation of caspase- 3 is the point of convergence of the intrinsic and extrinsic apoptotic pathways, leading to the common executive phase of apoptosis, and ultimately cell death. In our study, caspase-3 expression was significantly increased in IDOE-treated tumor cells compared with control cells.

Extensive DNA damage leads to activation of cell cycle check points and results in cell cycle arrest and apoptosis [17]. Accumulation of cells in the G2/M cell cycle phase was observed after $48 \mathrm{~h}$ of treatment with IDOE, indicating that the cells underwent G2/M arrest with this treatment in both cell lines.

\section{Conclusions}

IDOE inhibited the proliferation of breast cancer cells and lung carcinoma cells and induced caspase-3-mediated apoptosis and cell cycle arrest in the treated cells.

\section{Abbreviations}

IDOE: Isodeoxyelephantopin; DMSO: Dimethyl sulfoxide; PI: Propidium iodide; FBS: Fetal bovine serum; MTT: 3-(4,5-dimethylthiazol-2-yl)-2,5-diphenyltetrazolium bromide; PBS: Phosphate-buffered saline.

\section{Competing interest}

All authors declare that they have no competing interest.
Authors' contributions

FAK and RP conceived and designed the study. GBS, MSN, LPG, FAK and DSR performed the experiments. FAK wrote the manuscript. All authors read and approved the final manuscript.

\section{Acknowledgements}

This study was supported by the Kerala State Council for Science Technology and Environment (KSCSTE) (035/SRSLS/2007/CSTE) and University Grant Commission.

\section{Author details}

${ }^{1}$ Division of Cancer Research, Regional Cancer Centre, Thiruvananthapuram,

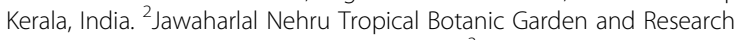
Institute, Thiruvananthapuram, Kerala, India. ${ }^{3}$ CSIR-National Institute for Interdisciplinary Science and Technology, Thiruvananthapuram, Kerala, India.

Received: 23 October 2013 Accepted: 11 April 2014

Published: 17 April 2014

\section{References}

1. Ho WY, Ky H, Yeap SK, Rahim RA, Omar AR, Ho CL: Traditional practice, bioactivities and commercialization potential of Elephantopus scaber Linn. J Med Plants Res 2009, 3(13):1212-1221.

2. Jain SK: Dictionary of Ethno-Veterinary Plants of India. New Delhi: Deep Publications; 1999

3. Ting H, Xia W, Ying W, Wen-Cai1 Y, Yao-Lan L: Chemical constituents of Elephantopus scaber. J Jinan Univ (Nat Sci Med Ed) 2009 5:553-555.

4. Ho WY, Yeap SK, Ho CL, Raha AR, Suraini AZ, Alitheen NB: Elephantopus scaber induces cytotoxicity in MCF-7 human breast cancer cells via p53-induced apoptosis. J Med Plants Res 2011, 5(24):5741-5749.

5. Huang CC, Lin KJ, Cheng YW, Hsu CA, Yang SS, Shyur LF: Hepatoprotective effect and mechanistic insights of deoxyelephantopin, a phytosesquiterpene lactone, against fulminant hepatitis. J Nutr Biochem 2012, 24(3):516-530.

6. Su M, Chung HY, Li Y: Deoxyelephantopin from Elephantopus scaber L. induces apoptosis in the human nasopharyngeal cancer CNE cells. Biochem Biophys Res Commun 2011, 411:342-347.

7. Kamalakannan P, Kavitha R, Elamathi R, Deepa T, Sridhar S: Study of phytochemical and antimicrobial potential of methanol and aqueous extracts of aerial parts of Elephantopus scaber L. Int J Curr Pharm Res 2012, 4(1):18-21.

8. Govindachari TR, Viswanathan N, Feuhrer H: Isodeoxyelephantopin a new germacranediolide from Elephantopus scaber Linn. Indian J Chem 1972, 10:272.

9. Xu G, Liang Q, Gong Z, Yu W, He S, Xi L: Antitumor activities of the four sesquiterpene lactones from Elephantopus scaber L. Exp Oncol 2006, 28(2):106-109.

10. Ichikawa H, Nair MS, Takada Y, Alan Sheeja DB, Kumar S, Oommen OV, Aggarwal BB: Isodeoxyelephantopin, a novel sesquiterpene lactone, potentiates apoptosis, inhibits invasion, abolishes osteoclastogenesis through suppression of nuclear factor $\mathrm{k} B$ activation and nuclear factor $\mathrm{k}$ B regulated gene expression. Clin Cancer Res 2006, 12(19):5910-5918.

11. Geetha BS, Mangalam SN, Latha PG, Remani P: Sesquiterpene lactones isolated from Elephantopus scaber L. inhibits human lymphocyte proliferation and the growth of tumour cell lines and induces apoptosis in vitro. J Biomed Biotechnol 2012, Article ID 721285:1-8.

12. Ghantous A, Muhtasib HG, Vuorela H, Saliba NA, Darwiche N: What made sesquiterpene lactones reach cancer clinical trials? Drug Discov Today 2010, 15(16):668-678.

13. Li W, Wang J, Jiang HR, Xu XL, Zhang J, Liu ML, Zhai LY: Combined effects of cyclooxygenase- 1 and cyclooxygenase- 2 selective inhibitors on ovarian carcinoma in vivo. Int J Mol Sci 2011, 12:668-681.

14. Khoo BY, Chua SL, Balaram P: Apoptotic effects of chrysin in human cancer cell lines. Int J Mol Sci 2010, 11:2188-2199.

15. Moongkarndi P, Kosem N, Kaslungka S, Luanratana O, Pongpan N, Neungton N: Antiproliferation, antioxidation and induction of apoptosis 
by Garcinia mangostana (mangosteen) on SKBR3 human breast cancer cell line. J Ethnopharmacol 2004, 90(1):161-166.

16. Budihardjo I, Olivier H, Lutter M, Luo X, Wang X: Biochemical pathways of caspase activation during apoptosis. Annu Rev Cell Dev Biol 1999,

15:269-290

17. Pietenpol JA, Stewart ZA: Cell cycle checkpoint signaling: cell cycle arrest versus apoptosis. Toxicology 2002, 181-182:475-481.

doi:10.1186/1749-8546-9-14

Cite this article as: Kabeer et al.: Isodeoxyelephantopin from Elephantopus scaber (Didancao) induces cell cycle arrest and caspase-3-mediated apoptosis in breast carcinoma T47D cells and lung carcinoma A549 cells. Chinese Medicine 2014 9:14.

\section{Submit your next manuscript to BioMed Central and take full advantage of:}

- Convenient online submission

- Thorough peer review

- No space constraints or color figure charges

- Immediate publication on acceptance

- Inclusion in PubMed, CAS, Scopus and Google Scholar

- Research which is freely available for redistribution 